\title{
Significance of rs 1271572 in the estrogen receptor beta gene promoter and its correlation with breast cancer in a southwestern Chinese population
}

\author{
Li Chen $^{1+}$, Yan Liang ${ }^{1 \dagger}$, Juhui Qiu², Lingling Zhang ${ }^{2}$, Xianchun Chen ${ }^{1}$, Xiangdong Luo ${ }^{2^{*}}$ and Jun Jiang ${ }^{1 *}$
}

\begin{abstract}
Background: To characterize single nucleotide polymorphisms (SNPs) within the promoter region of the estrogen receptor beta (ERß) gene and to analyze the association of ERß SNPs with susceptibility to breast cancer. Genotype frequencies of five SNPs (rs3020449, rs3020450, rs2987983, rs1271572 and rs1887994) in the promoter region of the ER $\beta$ gene in 873 women with breast cancer, 645 women with fibroadenoma and 700 healthy women were determined using an allele-specific tetra-primer polymerase chain reaction (PCR). Kaplan-Meier survival analysis was performed to evaluate the association of selected rs 1271572 with prognosis in breast cancer. Electrophoretic mobility-shift assays were conducted to explore the binding of SNP rs1271572 containing probes to transcriptional factor Ying Yang 1 (YY1).

Results: Women with the homozygous $\Pi$ genotype of rs 1271572 had a significantly higher risk in developing breast cancer. Breast cancer patients with the $\Pi$ genotype of rs 1271572 had lower five-year survival rates than those with other genotypes and were more likely to suffer brain metastases. The rs1271572 G $\rightarrow$ T SNP abrogated YY1 binding and reduced the transcription activity of the promoter $0 \mathrm{~N}$ in the ERß gene in vitro.

Conclusions: $\Pi$ genotype of rs 1271572 is associated with increased risk for breast cancer in Chinese women and is associated with unfavored prognosis in Chinese breast cancer patients. $\Pi$ genotype of rs 1271572 inhibited expression of ER $\beta$ gene by down regulating transcriptional activity of the promoter $0 \mathrm{~N}$ in the ER $\beta$ gene. Our data revealed that the $\Pi$ genotype of rs 1271572 resulted in loss of the YY1 binding site and reduced the transcription activity of the promoter $0 \mathrm{~N}$ in the ERß gene.
\end{abstract}

Keywords: Breast cancer, SNP, Estrogen receptor beta, Prognosis, Chinese

\section{Background}

Breast cancer is a worldwide health problem among women and causes an estimated 450,000 deaths annually [1]. In China,breast cancer is the most prevalent cancer in women and ranks as the 6th leading cause of death in Chinese women $[2,3]$. Single nucleotide polymorphisms (SNPs) are the most frequent sequence variations in the human genome [4]. Evidence from population studies

\footnotetext{
*Correspondence: luoxd2005@163.com; jiangjun8086@126.com ${ }^{\dagger}$ Equal contributors

${ }^{2}$ Burn Research Institute, Southwest Hospital, Third Military Medical University, Chongqing 400038, P. R. China

${ }^{1}$ Breast Disease Center, Southwest Hospital, Third Military Medical University, Chongqing 400038, P.R. China
}

have shown that some SNPs can affect breast cancer risk and survival.

ER $\beta$ (estrogen receptor $\beta$ ) plays a significant role in suppressing breast cancer cell proliferation [5] and acts as a negative modulator of ER $\alpha$ activity [6]. ER $\beta$ expression declines during breast tumorigenesis [7]; however, the mechanisms of ER $\beta$ down-regulation in breast cancer remain unclear. A few studies have reported an association between genotypic polymorphisms of ER $\beta$ with breast cancer susceptibility [8-10]. However, most of the population studies were performed in Europeans and Americans and the results have been inconsistent $[11,12]$. Currently, no such association studies have been performed in the Chinese populations.

\section{() Biomed Central}


SNPs located in exons may alter protein function, whereas SNPs in the gene promoter can modify gene expression levels $[13,14]$. Hirata et al. reported that transcription of the human ER $\beta$ gene occurs from at least two different promoters, named promoter $0 \mathrm{~N}$ and promoter $0 \mathrm{~K}$ [15]. Further studies have shown that transcripts from promoter $0 \mathrm{~N}$ are more prominent than those from promoter $0 \mathrm{~K}$ in normal breast epithelial cells and in a panel of breast cancer cell lines [16]. Based on a bioinformatics analyses of all the polymorphisms identified in the putative promoter of the ER $\beta$ gene, we selected five SNPs near the transcription start site of promoters $0 \mathrm{~N}$ of the ER $\beta$ gene (rs3020449 C/T, rs3020450 A/G, rs2987983C/T, rs1271572 G/T and rs1887994 G/T) as targets for the present study and characterized the five SNPs in the putative promoter of the ER $\beta$ gene in a population of Chinese women from southwest China. We also investigated whether an association exists between breast cancer risk and SNP rs1271572 G/T in the ER $\beta$ gene promoter and determined the effect of this SNP on $\mathrm{ER} \beta$ gene expression.

\section{Methods}

\section{Ethics statement}

The study was approved by the Ethical Committee of the Third Military Medical University and the Hospital Clinic Ethics Review Committee. Written informed consent was obtained from all participants involved in the study.

\section{Study subjects}

From January 2002 to December 2004, all the sporadic breast cancer patients with invasive ductal carcinoma who were selected to undergo surgery and adjuvant chemotherapy (cyclophosphamide $100 \mathrm{mg} / \mathrm{m}^{2} \mathrm{D} 1$, doxorubicin $30 \mathrm{mg} / \mathrm{m}^{2} \mathrm{D} 1,8$, and fluorouracil $500 \mathrm{mg} / \mathrm{m}^{2} \mathrm{D} 1,8$; all drugs given intravenously (IV) every 28 days, for a total of six cycles) were eligible for the present study. Diagnosis was confirmed using histologic examination of all specimens. Exclusion criteria included pregnancy, non-surgical candidates, patients unwilling to undergo treatment, patients with a family history of breast cancer, patients with congestive heart failure, ischemic heart disease, other malignancies, severe hepatic or renal dysfunction, altered mental status or patients who were over 70 years old. The patients $(n=873$; median age $45.8 \pm 12.5$ years, range $22-70$ years) were diagnosed at our Breast Disease Center at the Third Military Medical University and at the Affiliated Hospital of North Sichuan Medical College, China. Eighteen of the 873 patients were excluded because tetra-primer ARMS PCR failed. Since it was difficult to obtain a sufficient number of normal breast tissue samples, we chose to use tissues from fibroadenoma patients as controls in a scoring system for ER $\beta$ expression. The patients with fibroadenomas $(n=645$; median age $44.5 \pm 10.6$ years, range $18-69$ years) were enrolled after receiving appropriate informed consent. Fibroadenoma is not a premalignant disease. 700 healthy female blood donors (median age $41.5 \pm 12.1$ years, range $20-59$ years) with no history of any type of cancer or any relatives with a history of breast cancer were recruited for the present study as the second control group. The average age of incidence of breast cancer is 45.8. This is one of the criteria for selecting 700 cases of healthy controls. According to regulations in China, people over 60 years of age are not allowed to donate blood. Other factors in control groups are matched with those in breast cancer groups. In addition, the control subjects (patients with fibroadenomas and healthy female blood donors) should be drawn from the same population.

\section{Bioinformatics analyses of the ER $\beta$ gene promoter}

Our hypothesis is that SNPs in the promoter of the ERbeta gene could affect its expression, which could be a risk factor for breast cancer. Thus, we searched SNPs near the promoter of ER beta. The transcription of the human ER $\beta$ gene occurs from at least two different promoters, promoter $0 \mathrm{~N}$ and promoter $0 \mathrm{~K}$ [15]. AS transcripts from promoter $0 \mathrm{~N}$ were found to be more prominent than those from promoter $0 \mathrm{~K}[15,16]$, we referred to the NCBI database of known SNPs (http://www.ncbi.nlm.nih.gov/ snp/?term=ESR2, NCBI36/hg18) and selected five SNPs from the putative promoter region near the transcription start site of promoters (as shown in Additional file 1: Figure S1) 0 N: rs3020449, rs3020450, rs2987983, rs1271572 and rs1887994 that were also studied by others [8,17-20].

\section{Tetra-primer ARMS PCR}

Genomic DNA from blood was isolated using a Wizard Genomic DNA Purification Kit (Promega, USA) according to the manufacturer's instructions. The genomic DNA was resuspended in $50 \mu \mathrm{L}$ PCR buffer (GoTaq buffer, Promega, USA), containing 0.5\% Tween 20, 10 mAnson units proteinase $\mathrm{K}$ (Merck, Germany) and incubated at $50^{\circ} \mathrm{C}$ overnight. The mixture was then heated for $10 \mathrm{~min}$ at $95^{\circ} \mathrm{C}$ to inactivate the enzyme.

Allelic-specific tetra-primer amplification was performed on the genomic DNA using a tetra-primer ARMS PCR approach. Each PCR reaction was carried out in a total volume of $10 \mu \mathrm{l}$, containing $30 \mathrm{ng}$ of template DNA, 10 pmol of each inner primer, 1 pmol of each outer primer, $200 \mu \mathrm{M}$ dNTP, and 0.5 units Go Taq polymerase (Promega, USA). The reaction was overlaid with $5 \mu \mathrm{l}$ of liquid paraffin. The PCR cycling conditions for the detection of rs3020449 and rs3020450 were as follows: $95^{\circ} \mathrm{C}$ for $5 \mathrm{~min}$, then 33 cycles of $95^{\circ} \mathrm{C}$ for $1 \mathrm{~min}, 61^{\circ} \mathrm{C}$ for $1 \mathrm{~min}$, and $72^{\circ} \mathrm{C}$ $1 \mathrm{~min}$, followed by $72^{\circ} \mathrm{C}$ for $5 \mathrm{~min}$. For detecting rs2987983, rs1271572 and rs1887994, the following cycling conditions were utilized: $94^{\circ} \mathrm{C}$ for $5 \mathrm{~min}, 33$ cycles of $94^{\circ} \mathrm{C}$ 
for $30 \mathrm{~s}, 59^{\circ} \mathrm{C}$ for $1 \mathrm{~min}$ and $72^{\circ} \mathrm{C}$ for $1 \mathrm{~min}$, followed by $72^{\circ} \mathrm{C}$ for $5 \mathrm{~min}$. PCR products were mixed with $2 \mu \mathrm{l}$ of loading buffer and analyzed using 3\% agarose gel electrophoresis. The primers used for the PCR reaction are listed in Additional file 2: Table S1. Allelic-specific PCR product sizes were $353 / 250$ bp $(\mathrm{C} / \mathrm{T})$ for SNP rs3020449, 209/ 419 bp (A/G) for rs3020450, 276/164 bp (C/T) for rs2987983, 276/133 bp (G/T) for rs1271572 and 229/418 bp (G/T) for SNP rs1887994. The genotyping success rate was $97.8 \%$. As a quality control for genotyping, in each PCR reaction two previously characterized DNA samples representing the heterozygous and the two homozygous genotypes were analyzed in addition to the unknown samples. Genotyping was performed blinded without knowledge of the patients' clinical data.

\section{Cell culture}

Human breast cancer cell lines MDA-MB-231, MCF-7, MDA-MB-468, BT-549 and ZR75-30 (purchased from the American Type Culture Collection, Manassas, VA, USA), were maintained in modified MEM media supplemented with $10 \%$ fetal bovine serum (FBS), $2 \mathrm{mM}$ L-glutamine and $20 \mathrm{lg} / \mathrm{mL}$ gentamycin. Cell cultures were grown at $37^{\circ} \mathrm{C}$ in a humidified atmosphere with $5 \% \mathrm{CO}_{2}$ in a Hereaus $\mathrm{CO}_{2}$ incubator. To culture primary breast cancer cells, clinical resected breast cancer specimens were sheared to fractions, digested with trypsin/EDTA $(0.05 \% / 0.02 \%$ in PBS) for $20-30 \mathrm{~min}$ at $37^{\circ} \mathrm{C}$, followed by three washes with culture medium containing 10\% FBS. Following filtration through $56 \mu \mathrm{m}$ gauze, the single-cell suspension was then counted and seeded in six-well plates. After one week, the cancer cell clones were selected for culture. The primary breast cancer cells were identified using pathological examination.

\section{Plasmid construction, YY1 knock down, transient transfection and luciferase reporter assays}

The cDNA of promoter $0 \mathrm{~N}$ plus the partial upstream sequence of the intron up to the ATG transcriptional starting site in exon 1 (ESR2-0 $\mathrm{N}+-2316 \sim+1)$ and the cDNA of promoter $0 \mathrm{~K}$ plus the partial upstream sequence of the intron up to the ATG of exon 1 (ESR2-0 K + -1868 +1) (as shown in Additional file 3: Figure S2) were amplified from genomic DNA and the corresponding fragments were then subcloned into the Sac I and Hind III sites of the luciferase reporter vector, pGL3-basic (Promega) [10], to create pESR2-0 N-G-Luc (containing the $\mathrm{G}$ allele of rs1271572), pESR2-0 N-T-Luc (containing the $\mathrm{T}$ allele of rs1271572) and pESR2-0 K-Luc vectors. All vectors were confirmed by sequencing. To specifically knock down YY1, YY1-specific siRNA oligo sequences were used as follows: the siRNA target sequence: GACGACGACTACATTGAACAA; the siRNA sense: oligo r (CGACGACUACAUUGAACAA)dTdT; and the siRNA antisense oligo: r(UUGUUCAAUGUAGUCG UCG) dTdC.

Transient transfection was performed using FuGENE 6 reagent (Roche Applied Science) as described previously [5]. In brief, breast cancer cells growing from indicated cell lines or primary cultures were seeded into a 24-well plate at a density of $1 \times 10^{5}$ cells/well or in 6 -well plate at a density of $1 \times 10^{6}$ cells/well and were allowed to grow for 24 hours. $1.0 \mu \mathrm{g}$ of reporter gene constructs pRL alone or in combination with $5 \mathrm{nM}$ YY1-specific siRNA oligos were transiently transfected into these cells. 48 hours post transfection, cells were rinsed with PBS and then lysed in $1 \times$ passive lysis buffer. Luciferase activity was determined using a dual-luciferase reporter assay kit (Promega). The ratio of firefly luciferase activity was normalized to Renilla luciferase activity. The pGL3-control (Promega) was also used as an additional control in these experiments.

\section{Electrophoretic mobility-shift assay (EMSA)}

Nuclear extract preparation and EMSAs were performed as previously described [21] with slight modifications. In brief, a thawed breast cancer cell pellet was first lysed in ice-cold Buffer A (25 mM Tris- $\mathrm{HCl}, \mathrm{pH} 7.5,50 \mathrm{mM}$ $\mathrm{KCl}, 2 \mathrm{mM} \mathrm{MgCl}_{2}, 5 \mathrm{mM}$ dithiothreitol, and inhibitors of phosphatases). After removing supernatants by centrifugation, buffer $\mathrm{C}(20 \mathrm{mM}$ Tris- $\mathrm{HCl}, \mathrm{pH} 7.5,0.42 \mathrm{M}$ $\mathrm{NaCl}, 1.5 \mathrm{mM} \mathrm{MgCl}_{2}, 25 \%$ sucrose, $1 \mathrm{mM}$ dithiothreitol, and inhibitors of phosphatase) was added and gently shaked for $30 \mathrm{~min}$ at $0^{\circ} \mathrm{C}$. The supernatants were collected and concentration of nuclear proteins was measured. The oligonucleotides probes containing the two SNP alleles of the human ER $\beta$ gene promoter region were as follows: probe-rs1271572G (with the $G$ allele), 5'-TGTGACAC TGGGGGGGTCTCACAATGGCCT-3'; and probers1271572T (with the T allele), 5'-TGTGACACTGGGGG GTTCTCACAATGGCCT-3'. The double-stranded DNA probes were end-labeled with $\gamma-{ }^{32} \mathrm{P}$ ATP and T4polynucleotide kinase (Promega). The nuclear proteinDNA binding reaction was performed at $37^{\circ} \mathrm{C}$ for $20 \mathrm{~min}$ in a total volume of $20 \mu \mathrm{l}$ containing $10 \mu \mathrm{g}$ nuclear extract proteins and $0.2 \mathrm{ng}$ of labeled double probes or a 50 -fold non-labeled competitor probe. The DNA-protein complexes were resolved by electrophoresis through a $4 \%$ poly-acrylamide gel. Gels were dried and the labeled complexes were detected by autoradiography.

\section{Immunohistochemistry}

The breast specimens from patients with breast cancer or fibroadenoma were fixed in a $0.1 \mathrm{M}$ phosphate-buffered $10 \%$ formaldehyde solution for $24 \mathrm{~h}$, dehydrated, and embedded in paraffin ( $5 \mu \mathrm{m}$ sections were used). The primary antibody dilutions found to be optimal for this study were 1:500 for ER $\beta$ (mAb, Chemicon International). All data on ER $\alpha, \operatorname{PgR}$, and HER2 status were retrieved 
from pathology reports performed by a pathologist (positives are defined when more than $10 \%$ of tumor cells are stained). The specificity of the immunohistochemical procedures was checked using negative and positive control sections.

A scoring system for ER $\beta$ expression in the tissues was used as follows: no staining ( 0 points), weak staining ( 1 point, staining in less than $20 \%$ of tumor cells), low staining (2 points, staining in $21-40 \%$ of tumor cells), medium staining (3 points, staining in $41-60 \%$ of tumor cells), and high staining (4 points, staining in over $61 \%$ of tumor cells) tissues. Each tissue has three different slides. The typical slice including the center and edge of cancer were chosen and total positive cancer cell rate was calculated as the score for that tissue by a pathologist. A total of 1,483 immunohistochemically stained ER $\beta$ tissues (from 628 fibroadenoma and 855 breast cancer) underwent central review.

\section{Statistical analyses}

The allelic and genotypic frequencies for each SNP were calculated, and deviation from the Hardy-Weinberg equilibrium was estimated using a $\chi^{2}$ test. The differences in allelic and genotypic frequencies between the breast cancer group, the fibroadenoma group, and the healthy blood donor group were estimated and statistical tests for association (95\% confidence interval [CI]) and for significance were performed using SPSS (version 14) for Windows (SPSS, Inc., Chicago, IL) and SHEsis (http://analysis.bio-x.cn/myAnalysis.php). The results were considered to be significant when $p<0.05$.

Cause-specific survival was defined as the time from diagnosis to death if the patient died of breast cancer, or to last known contact. Data for patients who died from causes other than breast cancer, who missed follow-up or for whom contact was interrupted, were censored. The Kaplan-Meier method with a log-rank test was used to establish the significance of genotypes of rs1271572 as predictors of Survival Probability (SP). For the 631 women with breast cancer, the same test was used to compare differences between the different groups defined by the G/T genotypes of rs1271572 (promoter of ER $\beta$ gene), by their ER $\beta$-positive and ER $\beta$-negative status, their ER $\alpha$-positive and ER $\alpha$-negative status, their HER2positive and HER2-negative status, or their PgR-positive and PgR-negative status.

Cox proportional hazards models were used to test for association of survival times of patients to their rs1271572 genotypes and to clinical characteristics, such as menopause, age, tumor size, nodal status, breast cancer grade, and ER $\alpha /$ HER $2 /$ PgR status. The $95 \%$ CI was used to quantify the relationship between survival time and each independent factor. All tests were 2 -sided, and $p$ values $<0.05$ were considered to be statistically significant.

\section{Results and discussion}

\section{The $\mathrm{rs} 1271572 \mathrm{G} \rightarrow \mathrm{T}$ genotype is associated with breast} cancer

As a negative regulator of $E R \alpha, E R \beta$ plays a critical role in breast cancer development. A number of common polymorphisms have been identified in the ER $\beta$ gene $[11,12]$, with variable degrees of evidence of their direct biological significance and their association with human diseases [22-25]. A total of five SNPs in the promoter region of the ER $\beta$ (ESR2) gene were selected (http:// www.ncbi.nlm.nih.gov/snp) as candidates for conferring variations in all 1,518 patients (873 with breast cancer and 645 with breast fibroadenoma) and in the 700 healthy blood donors. The tetra-primer ARMS-PCR method was successfully applied to five different SNPs in the promoter of the ER $\beta$ gene, i.e. the rs3020449 $\mathrm{C} \rightarrow \mathrm{T}$, rs3020450 A $\rightarrow$ G, rs2987983 C $\rightarrow$ T, rs1271572 G $\rightarrow$ T and rs1887994 $\mathrm{G} \rightarrow \mathrm{T}$ polymorphisms. The genotypes determined using this method were consistent with those determined by the classical restriction endonuclease digestion method [26].

Genotyping results for the selected 5 SNPs were summarized in Additional file 4: Table S2. Specifically, the frequencies of the genotypes for rs3020449, rs3020450 and rs1271572 were in Hardy-Weiberg equilibrium (http:// analysis.bio-x.cn/myAnalysis.php) $(p>0.05)$ in this set of study population. No significant differences were observed for the homozygous/heterozygous genotype frequencies of SNPs rs3020449 and rs3020450 among the three groups. A higher frequency of the homozygous TT genotype in rs1271572 was observed in women with breast cancer compared with those with fibroadenoma $(p=0.00019)$ or healthy controls $(\mathrm{p}=0.0008)$. There was no significant difference in the TT genotype frequencies between the fibroadenoma group and the blood donors group. In addition, the genotype-phenotype association suggests that the TT genotype of rs1271572 is a risk factor for breast cancer development (cancer group vs. blood donors group: Odds Ratio $(\mathrm{OR})=0.546$, [95\%CI 0.404-0.739], $\mathrm{X}^{2}=15.54, p=0.00008$; and cancer group $v s$. fibroadenoma group: $\mathrm{OR}=0.558, \quad[95 \% \mathrm{CI} \quad 0.409-0.759], \chi^{2}=13.89$, $p=0.00019)$.

The defect in PCR primer resulted in experimental failure of the rs2987983. Indeed, the relationship between SNPs in the promoter region and expression of ERbeta has seldom been reported in China. Our studies are mainly from a foreign population, which may cause rs1887994 selection failure. In addition, we did not do Bonferroni adjustment, as only a few sites were analyzed.

Our analyses of the allelic frequencies of the five selected ER $\beta$ SNPs in these study subjects revealed that women with breast cancer more frequently carried the $\mathrm{T}$ allele of SNP rs1271572 [cancer 45.03\% vs. blood donors 38.35\%, $\mathrm{OR}=1.310$, 95\% CI (1.060-1.619), $\chi^{2}=6.27, p=0.01229$; 


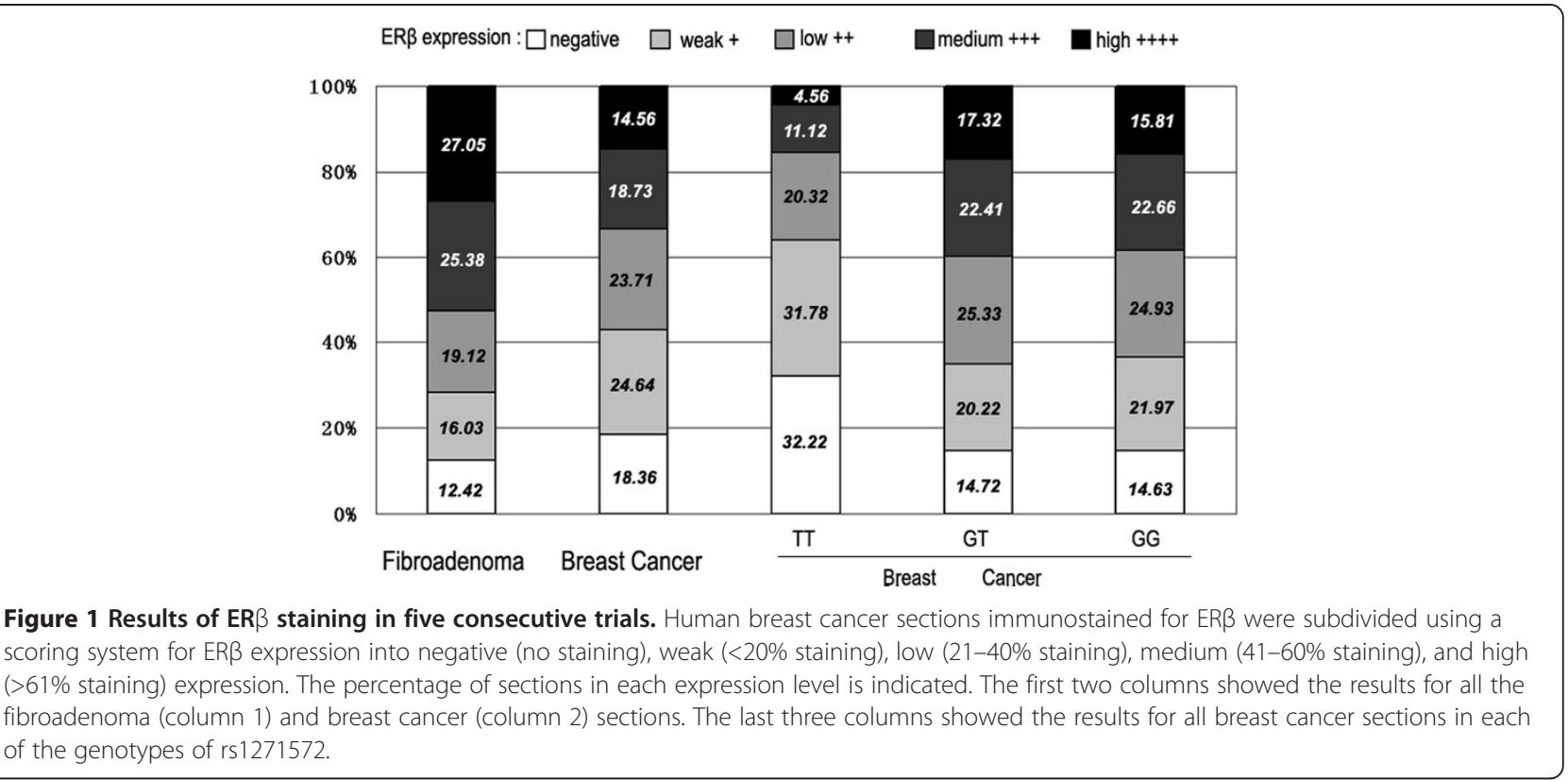

cancer $45.03 \%$ vs. fibroadenoma $38.38 \% \mathrm{OR}=1.331,95 \%$ CI (1.072-1.654), $\chi^{2}=6.69, p=0.00969$ ]. In contrast, no significant difference in the allelic frequencies of SNPs rs3020449 and rs3020450 were detected among the three groups.

The SNPs in the promoter $0 \mathrm{~N}$ region of the ER $\beta$ gene may affect breast cancer risk. Treeck provided evidence that the CC genotype of rs 2987983 could be a risk factor for breast cancer development [8]. A recent report showed that homozygotes for the ER $\beta$ gene rs1271572/T are risk factors for postmenopausal breast cancer treated with hormone therapy [18]. The rs 1271572 polymorphism is also associated with prostate cancer risk among Chinese men [20]. However, another study showed that none of the SNPs in the ER $\beta$ gene promoter (including rs1271572) were independently associated with breast cancer risk [19]. Thus, the association of rs1271572 with breast cancer remains controversial. But we reported that the

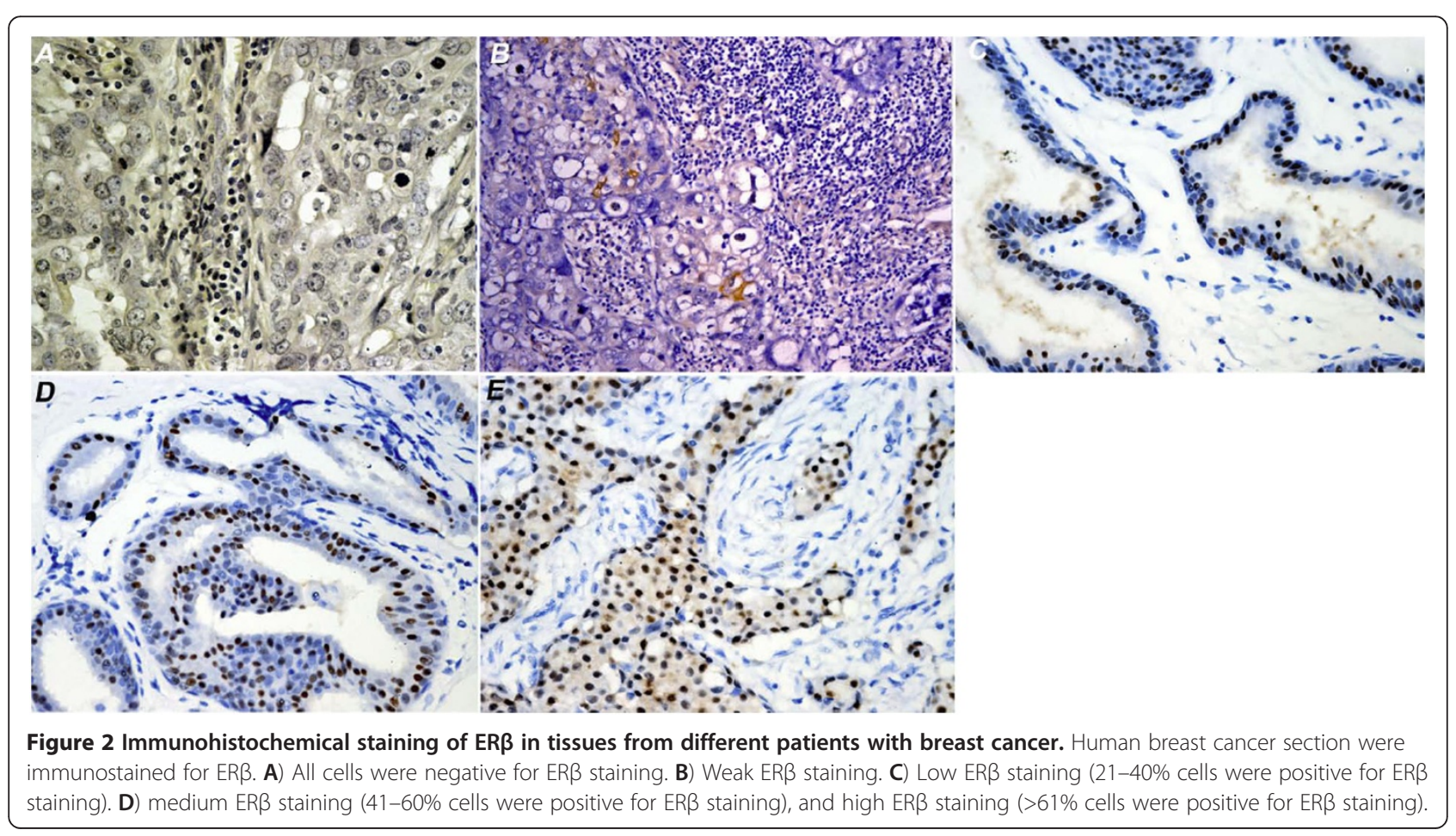


Table 1 Relationship between the genotypes of rs1271572 and ER $\beta$ status in Chinese patients with breast cancer or fibroadenomas

\begin{tabular}{|c|c|c|c|c|c|c|}
\hline \multicolumn{4}{|c|}{ Cancer patients, $\mathrm{n}(\%)$} & \multicolumn{3}{|c|}{ Fibroadenoma patients, n (\%) } \\
\hline rs1271572 & ER $\beta$-positive & ER $\beta$-negative & $p$ value & ER $\beta$-positive & ER $\beta$-negative & $p$ value \\
\hline$\overline{\mathrm{GG}}$ & $226(26.43)$ & $39(4.56)$ & & $205(32.64)$ & $30(4.78)$ & \\
\hline GT & $350(40.94)$ & $60(7.02)$ & $<0.001$ & $266(42.36)$ & $38(6.05)$ & 0.93 \\
\hline$\pi$ & $122(14.27)$ & $58(6.78)$ & & $79(12.58)$ & $10(1.59)$ & \\
\hline GG & $226(26.43)$ & $39(4.56)$ & & $205(32.64)$ & $30(4.78)$ & \\
\hline $\mathrm{GT}+\mathrm{TT}(\mathrm{T}$ carrier $)$ & $472(55.20)$ & $118(13.80)$ & 0.07 & $345(54.94)$ & $48(7.64)$ & 0.901 \\
\hline
\end{tabular}

TT genotype of rs1271572 was present at a significantly higher frequency in breast cancer patients than in fibroadenoma patients or in the blood donor control group $(p<0.001)$, suggesting for the first time that the TT genotype of rs1271572 in the ER $\beta$ gene promoter might be an important risk factor for breast cancer in Chinese women.

\section{TT genotype of rs1271572 was associated with} downregulation of ER $\beta$ expression in breast cancer As shown in Figure 1, no or weak staining for ER $\beta$ was presented in less than $30 \%$ of fibroadenoma tissues, whereas it was observed in nearly $40 \%$ of the breast cancer tissues. Nearly $40 \%$ of the breast cancer tissues exhibited either no staining or weak staining for ER $\beta$ compared with $<30 \%$ for fibroadenoma tissues. Negative ER $\beta$ expression was more frequently observed in breast cancer patients $(18.36 \%)$ than that in the fibroadenoma group (12.42\%). Among the breast cancer patients with negative ER $\beta$ expression, the proportion of patients carrying the TT genotype (32.22\%), was higher than that carrying the GG (14.63\%) and GT (14.72\%) subgroups combined $(p<0.05)$. Similarly, among breast cancer patients with weak ER $\beta$ expression, the proportion of patients carrying the TT genotypes of rs1271572 (31.78\%) was higher than for the other subgroups, GG (21.97\%) and GT (20.22\%) $(p<0.05$, Figure 1$)$. Together, these results indicated that in the breast cancer patients, the TT genotype of rs1271572 was strongly associated with negative or weak ER $\beta$ gene expression. Expression of ER $\beta$ was determined using immunohistochemical staining. Representative staining images with different scores were shown in Figure 2.

We also compared the genotype frequencies of rs1271572 (GG, GT and TT) between the ER $\beta$-positive and ER $\beta$-negative subgroups. The genotypes (GG, GT and TT) of rs1271572 between the ER $\beta$-positive and ER $\beta$-negative subgroups were found to be significantly different in cancer patients $(p<0.001)$. Although frequencies of the GG and GT carrier was not significantly different between the ER $\beta$-positive and ER $\beta$-negative subgroups $(p=0.07)$, the frequency of TT genotype was significantly lower $(p<0.001)$ than that of the other genotypes in ER $\beta$-positive patients. In breast fibroadenoma patients, all genotypes and $\mathrm{T}$ carrier were similarly distributed between ER $\beta$-positive and ER $\beta$-negative breast fibroadenoma patients $(p=0.930$ and $p=0.901$ respectively) (Table 1).

We next analyzed the genotypic frequencies of rs1271572 in ER $\beta$-positive cases between patients with breast cancer and fibroadenoma. Although ER $\beta$-positive cases were more frequently detected in fibroadenoma patients $(p=0.002$, Table 2), ER $\beta$-positive cases with rs1271572 TT genotype was less frequently detected in breast cancer patients $(p<0.001$, Table 2$)$. The genotypic frequencies of GT and GG showed no significant difference between these two subgroups.

Importantly, our results strongly suggest that the TT genotype of rs1271572 may be associated with downregulation of ER $\beta$ expression in breast cancer (Figures 1 and 2, Tables 1 and 2).

Table 2 Relationship between the genotypes of rs1271572 and the ER $\beta$-positive groups of breast cancer and fibroadenoma patients

\begin{tabular}{lcccc}
\hline Groups & Patients, $\mathbf{n}(\%)$ & GG & GT & TT \\
\hline Cancer & & & & \\
ERß-positive & $698 / 855(81.64)$ & $226 / 265(85.28)$ & & \\
Fibroadenoma & & & & $122 / 180(67.78)$ \\
ERß-positive & $550 / 628(87.58)$ & $205 / 235(87.23)$ & $266 / 304(87.50)$ & $79 / 89(88.76)$ \\
OR & 0.631 & 0.848 & 0.858 & 0.266 \\
Cl 95\% & $0.470-0.846$ & $0.508-1.415$ & $0.556-1.324$ & $0.129-0.552$ \\
P value & 0.002 & 0.528 & 0.49 & $<0.001$ \\
\hline
\end{tabular}


Table 3 Factors influencing the risk of death using multivariate Cox regression analyses

\begin{tabular}{|c|c|c|c|}
\hline Variable & $\begin{array}{c}\text { Hazard } \\
\text { ratio }\end{array}$ & $95 \% \mathrm{Cl}$ & $\begin{array}{c}\text { Wald test } \\
p \text { value }\end{array}$ \\
\hline Genotypes (TT $\vee \mathrm{GT} / \mathrm{GG}$ ) & 2.58 & $1.31 \sim 3.79$ & 0.0065 \\
\hline ERß (negative $v$ positive) & 1.67 & $0.71 \sim 1.67$ & 0.027 \\
\hline ERa (negative $v$ positive) & 0.81 & $0.67 \sim 0.98$ & 0.035 \\
\hline HER2 (negative $v$ positive) & 1.78 & $0.76 \sim 1.87$ & 0.015 \\
\hline Tumor size $(<20 \mathrm{~mm} \mathrm{v} \geq 20 \mathrm{~mm})$ & 0.96 & $0.62 \sim 1.51$ & 0.951 \\
\hline Nodal status (positive $v$ negative) & 1.21 & $0.53 \sim 1.83$ & 0.14 \\
\hline TNM (T3-4 v T1-2) & 1.67 & $0.83 \sim 1.94$ & 0.054 \\
\hline menopause (premenopausal $v$ post) & 1.26 & $1.03 \sim 1.78$ & 0.058 \\
\hline age $(\geq 50 v<50)$ & 0.86 & $0.83 \sim 1.21$ & 0.24 \\
\hline PgR(positive $v$ negative) & 0.97 & $0.76 \sim 1.09$ & 0.21 \\
\hline
\end{tabular}

\section{TT genotype of rs1271572 was a risk factor for breast} cancer-related death

Univariate and multivariate analyses were first performed to examine whether rs1271572 genotypes were associated with clinical parameters in breast cancer. No significant association was observed between the frequency of either the homozygous TT or heterozygous GT genotypes of rs1271572 and the clinical characteristics including tumor size, menopause, age, lymph node positive, breast cancer related receptors status (ER- $\alpha$, PgR, HER2) or breast cancer stage (TNM) in patients with breast cancer (Additional file 5: Table S3).

Multivariate Cox regression analyses were next performed to explore whether rs1271572 genotypes were associated with breast cancer susceptibility. As shown in Table 3, the TT genotype of rs1271572 was an independent risk factor for cancer-related death in breast cancer women (hazard ratio: 2.58; 95\% CI: $1.31 \sim 3.79 ; p=0.0065)$. Other statistically significant variables associated with cancer-related death included ER $\beta$ (hazard ratio: 1.67, $p=0.027$ ), ER- $\alpha$ (hazard ratio: $0.81, p=0.035$ ), and HER2 (hazard ratio: $1.78, p=0.015)$. Interestingly, the clinical tumor size, nodal status, TNM, menopause, age and PgR status did not show statistically significant associations with cancer-related death in this cohort of breast cancer patients.
A
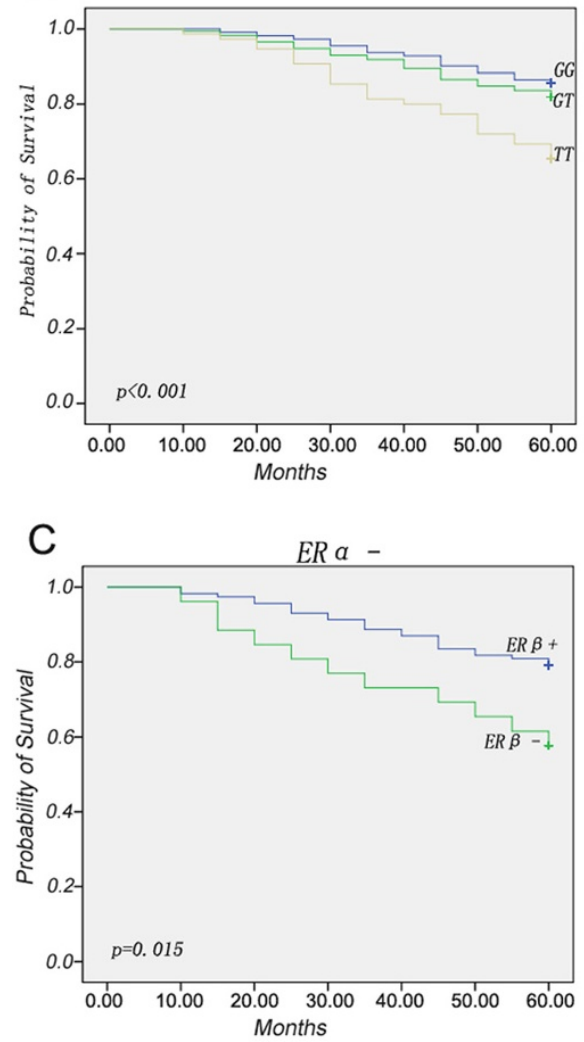

B

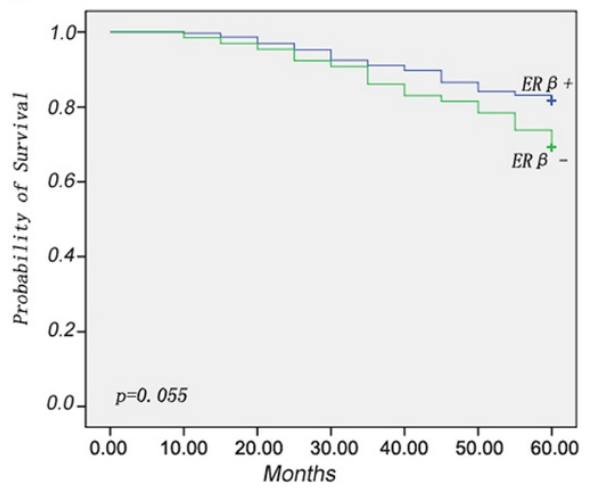

$D$

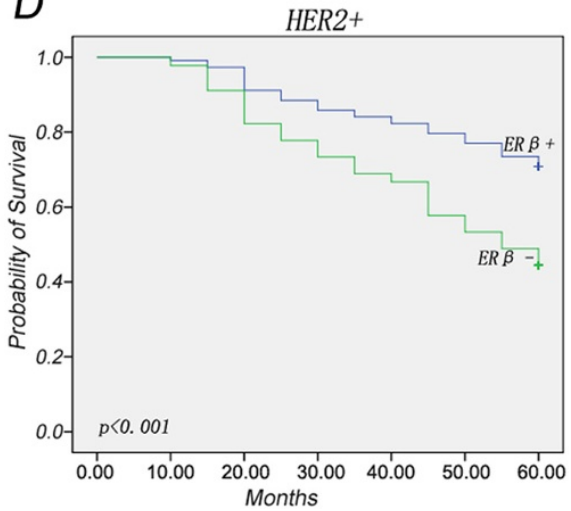

Figure 3 TT genotype of rs1271572 was associated with worse survival in breast cancer. Kaplan-Meier breast cancer-free survival was applied to determine the prognosis $\mathbf{A}$ ) among patients with the three genotypes (GG, GT and TT) of rs1271572; B) between ERß-positive and $E R \beta$-negative patients; $\mathbf{C}$ ) between $E R \beta$-negative and ER $\beta$-positive patients in the ER- subgroup, and $\mathbf{D}$ ) between ER $\beta$-negative and ER $\beta$-positive patients in the Her + patients. The $p$ values were determined using the log-rank test; a significant difference was assumed for $p<0.05$. 
Table 4 The relationship of the genotypes of rs1271572 with the occurrence and location of distant metastases five years following diagnosis

\begin{tabular}{|c|c|c|c|c|c|c|}
\hline & \multirow{2}{*}{$\begin{array}{l}\text { Recurrence } \\
\text { rate } \mathrm{n}(\%)\end{array}$} & \multicolumn{5}{|c|}{ Distant metastasis n (\%) } \\
\hline & & Lung & Liver & Brain & Bone & Other \\
\hline Breast cancer & $218 / 835(26.11)$ & $70 / 218(32.12)$ & $42 / 218(19.27)$ & $33 / 218(15.14)$ & $52 / 218(23.85)$ & $21 / 218(9.63$ \\
\hline GG & $58 / 252(23.02)$ & 20/58(34.48) & 12/58(20.69) & $6 / 58(10.34)$ & 11/58(18.97) & $9 / 58(15.52)$ \\
\hline GT & $95 / 404(23.51)$ & $36 / 95(37.89)$ & 17/95(17.89) & 9/95(9.47) & 26/95(27.37) & 7/95(7.37) \\
\hline TT & 65/179(36.31) & $15 / 65(23.08)$ & 13/65(20.00) & 19/65(29.23) & $12 / 65(18.46)$ & 6/65(9.23) \\
\hline$p$ value & 0.065 & 0.231 & 0.904 & 0.005 & 0.835 & 0.483 \\
\hline
\end{tabular}

Multivariate analyses revealed that the TT genotype of rs1271572, ER $\alpha$ and HER2, is an independent prognostic factor for risk of cancer-related death in breast cancer patients (Table 3). All these strongly suggest that TT genotype of rs1271572 is a functionally important SNP in breast cancer. Our finding that ER $\beta$ is related to a favorable outcome is consistent with previous report by of Vinayagam et al. [27].

\section{TT genotype of rs1271572 was associated with poor prognosis and higher risk of brain metastasis}

The median follow up period was 43.24 (range 8.2-62.46) months for the participated cancer patients, and the mean follow up period was 49.33 months. The Kaplan-Meier survival analyses demonstrated that patients with the TT genotype of rs1271572 had a shorter survival rate than patients with the GG or GT genotypes of rs1271572 $(p<0.001$, Figure 3A). No significant difference in survival rates between ER $\beta$-positive and ER $\beta$-negative patients $(p=0.055$, Figure $3 \mathrm{~B})$ was observed. However, among ER $\alpha$-negative and Her2-positive cases, ER $\beta$-negative patients had a shorter survival rate than ER $\beta$-positive patients ( $p=0.015$ and $p<0.001$, respectively) (Figure 3C and $3 \mathrm{D})$. However, among ER $\alpha$-positive and Her2-negative cases, no correlations were observed between the expression levels of ER $\beta$ and survival rates (data not shown). In addition, we found that breast cancer patients with the TT genotype of rs1271572 were more likely to suffer brain metastases $(29.23 \%)$ than patients with the GG $(10.34 \%)$ or GT $(9.47 \%)$ genotypes $(\mathrm{p}=0.005)$ (Table 4). The location of distant metastases was recorded for the first metastatic organ found during the follow-up period. Data for patients with multiple organ metastasis first diagnosed during follow-up, were grouped in "other" in Table 4.

Our results demonstrated that patients with the TT genotype of rs1271572 had significantly poorer five-year survival rates (Figure 3A) and were more likely to suffer brain metastases (Table 4) than patients with the other two genotypes. ER $\beta$ expression modulates adhesion and migration of breast cancer cells [28], suggesting that the TT genotype of rs1271572 might promote brain metastases of breast cancer by suppressing ER $\beta$ gene expression.

Although there was no significant difference in cancerfree survival between the ER $\beta$-positive and ER $\beta$-negative subgroups ( $p=0.055$, Figure $3 \mathrm{~B}$ ) among breast cancer patients, the TT homozygotes had poorer survival rates $(\mathrm{p}<0.001$ Figure $3 \mathrm{~A})$. This apparent contradiction might be because, in the TT genotype subgroup, patients with both ER $\beta$-negative and ER $\beta$ weak expression (nearly 64\%) were included. Moreover, ER $\beta$-negative/ER $\alpha$-negative breast cancer patients had significantly poorer survival rates compared with patients in the ER $\beta$-positive/ER $\alpha-$ negative subgroup $(p=0.015$, Figure $3 C)$. This result is

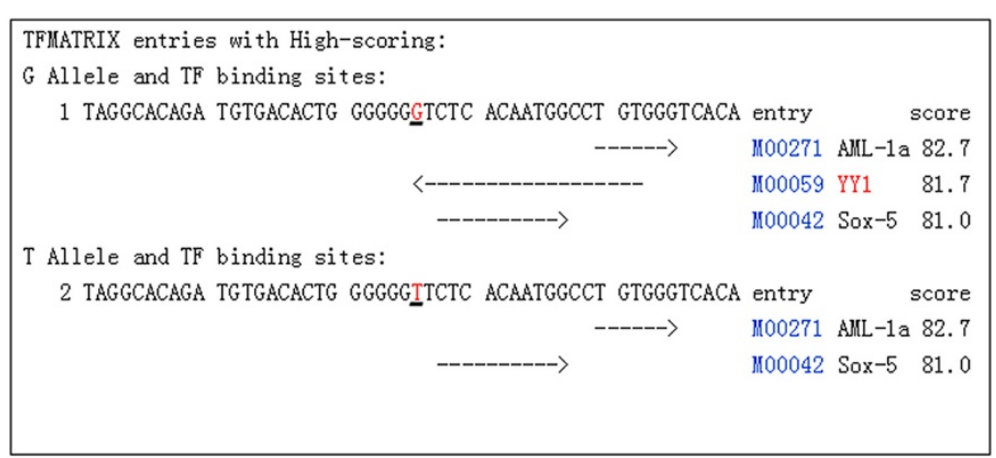

Figure 4 Prediction of TF binding sites in the different alleles of rs1271572. The results from the TFSEARCH (http://www.cbrc.jp/research/ $\mathrm{db} /$ TFSEARCH.html) prediction of transcription factor binding sites in the ER $\beta$ promoter were shown. The T allele of rs 1271572 resulted in the loss of the Yin Yang 1 (YY1) transcription factor binding site. 
consistent with the findings of an earlier report that ER $\beta$, particularly in ER $\alpha$-negative patients, was associated with increased survival (distant disease-free survival) rates [29]. Rakha et al. recently reported that HER2 + was the poorest prognostic factor among different molecular subtypes [30]. In Her2 positive patients, ER $\beta$-negative patients had significantly poorer survival rates compared in the ER $\beta-$ positive patients $(p<0.001$, Figure $3 D)$, suggesting that ER $\beta$-positivity confers a better outcome for patients with the poor prognostic factors including ER $\alpha$-negative and HER2 -positive. All of the results reported here support the finding that detection of ER $\beta$ status in breast cancer tissues may provide clinically useful information in addition to the well established ER $\alpha / \mathrm{HER} 2 / \mathrm{PgR}$ assay.

The rs1271572 T allele may be associated with loss of Yin Yang 1 binding in ER $\beta$ promoter $0 \mathrm{~N}$ and suppress ER $\beta$ expression in breast cancer

Transcription of the human ER $\beta$ gene occurs from at least two different promoters, promoter $0 \mathrm{~N}$ and promoter $0 \mathrm{~K}$, with promoter $0 \mathrm{~N}$ being more prominent in breast epithelial cells and breast cancer cells [15] [16]. As the TT genotype of rs1271572 is significantly associated with low ER $\beta$ expression in breast cancer patients (Figure 1), we hypothesized that certain transcriptional factors (TFs) that are critical to regulate ER $\beta$ expression specifically bind to $\mathrm{G}$ allele, but not $\mathrm{T}$ allele containing promoters. To search for TFs that differently bind to these promoters, bioinformatics approaches (http://www.cbrc.jp/ research/db/TFSEARCH.html; http://variome.kobic.re. $\mathrm{kr} / \mathrm{SNPatPromoter} /$ ) were used which showed that the rs1271572 $\mathrm{T}$ allele could result in the loss of the Yin Yang 1 (YY1) transcription factor binding (Figure 4). We speculated that the loss of the YY1 binding site might be involved in the decreased expression of the $\mathrm{ER} \beta$ gene.

To explore the role of the T allele in YY1 binding, binding activity of the two probes that contain sequence from either rs1271572G or rs1271572T was compared using EMSA in a panel of breast cancer cell lines. As shown in Figure 5, specific protein-DNA complex were detected with probe rs1271572G but not probe rs1271572T. Moreover, supershift with YY1 antibody indicated that YY1 was specifically bound to the rs1271572G oligo in these cells. Our data have shown that except for YY-1, other transcriptional factors could not bind to the region of rs1271572G and that YY-1 lost its capacity to bind to the region of rs1271572(T) (Figure 5).

To further determine whether the T allele of rs1271572 confers decreased transcriptional activity of the ER $\beta$ gene promoter, we compared the luciferase reporter activity of pESR2-0 N-G-Luc and pESR2-0 N-T-Luc. Indeed, the reporter activity of pESR2-0 N-T-Luc was significantly lower that of pESR2-0 N-G-Luc, (Figure 6A and 6B),

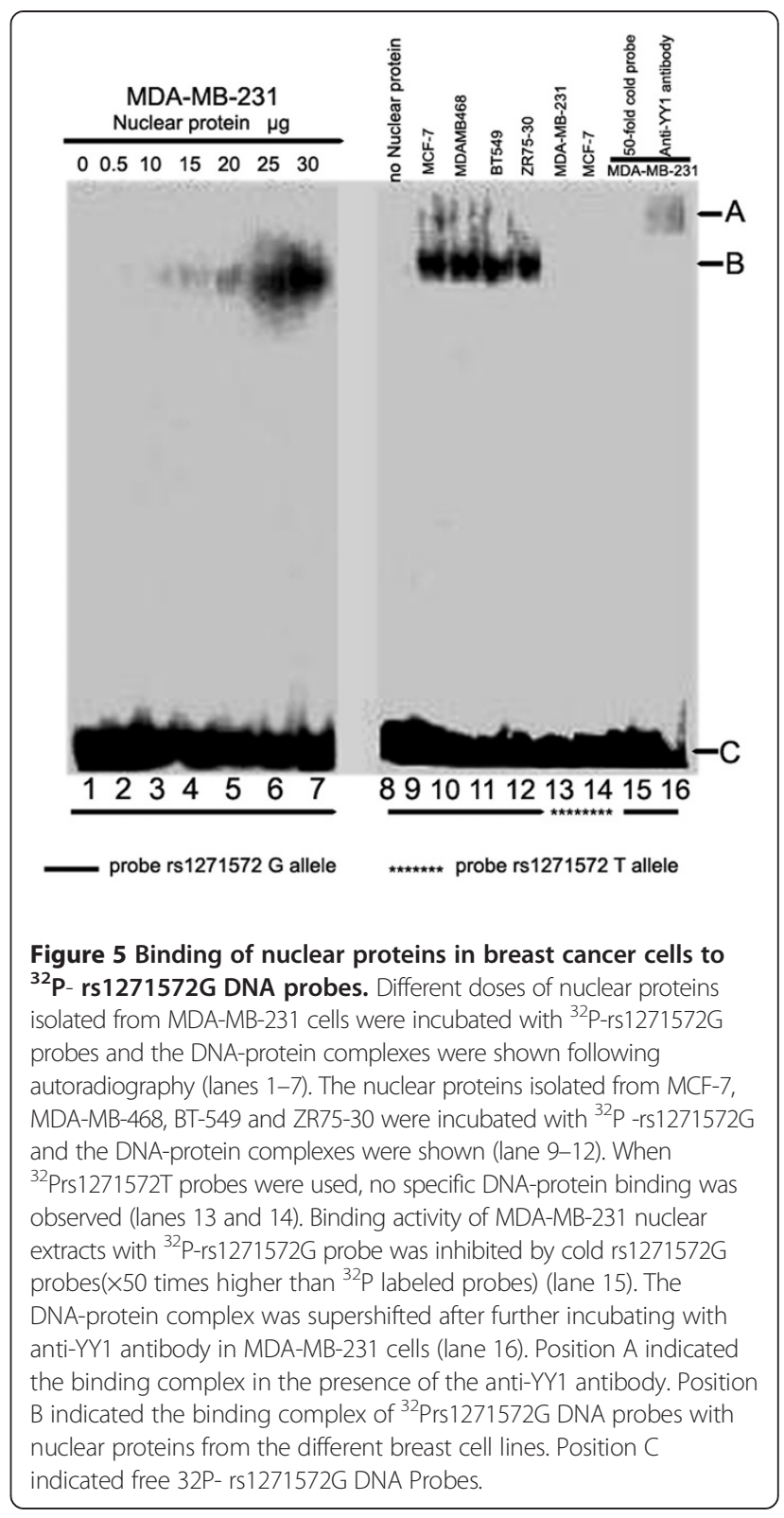

suggesting that the $\mathrm{T}$ allele of rs1271572 could lead to a decrease in the transcription activity of the ER $\beta$ gene promoter $0 \mathrm{~N}$. In agreement with a previous report that transcripts from promoter $0 \mathrm{~N}$ were more prominent than those from promoter $0 \mathrm{~K}$ [16], we also observed that the luciferase activity of pESR2-0 K-Luc was significantly weaker than that of pESR2-0 N-G-Luc in the five breast cancer cell lines and in the primary cancer cells of two patients. Interestingly, luciferase activity of pESR2-0 N-G-Luc but not pESR2-0 N-T-Luc was dramatically decreased in these cells when co-transfected with YY1-specific siRNA oligos along with pESR2-0 N-G-Luc, pESR2-0 N-T-Luc or pESR2-0 $\mathrm{K}$-Luc, indicating that YY1 is involved in regulation of the activity of ER $\beta$ gene promoter $0 \mathrm{~N}$ (Figure 6A and 6B). 

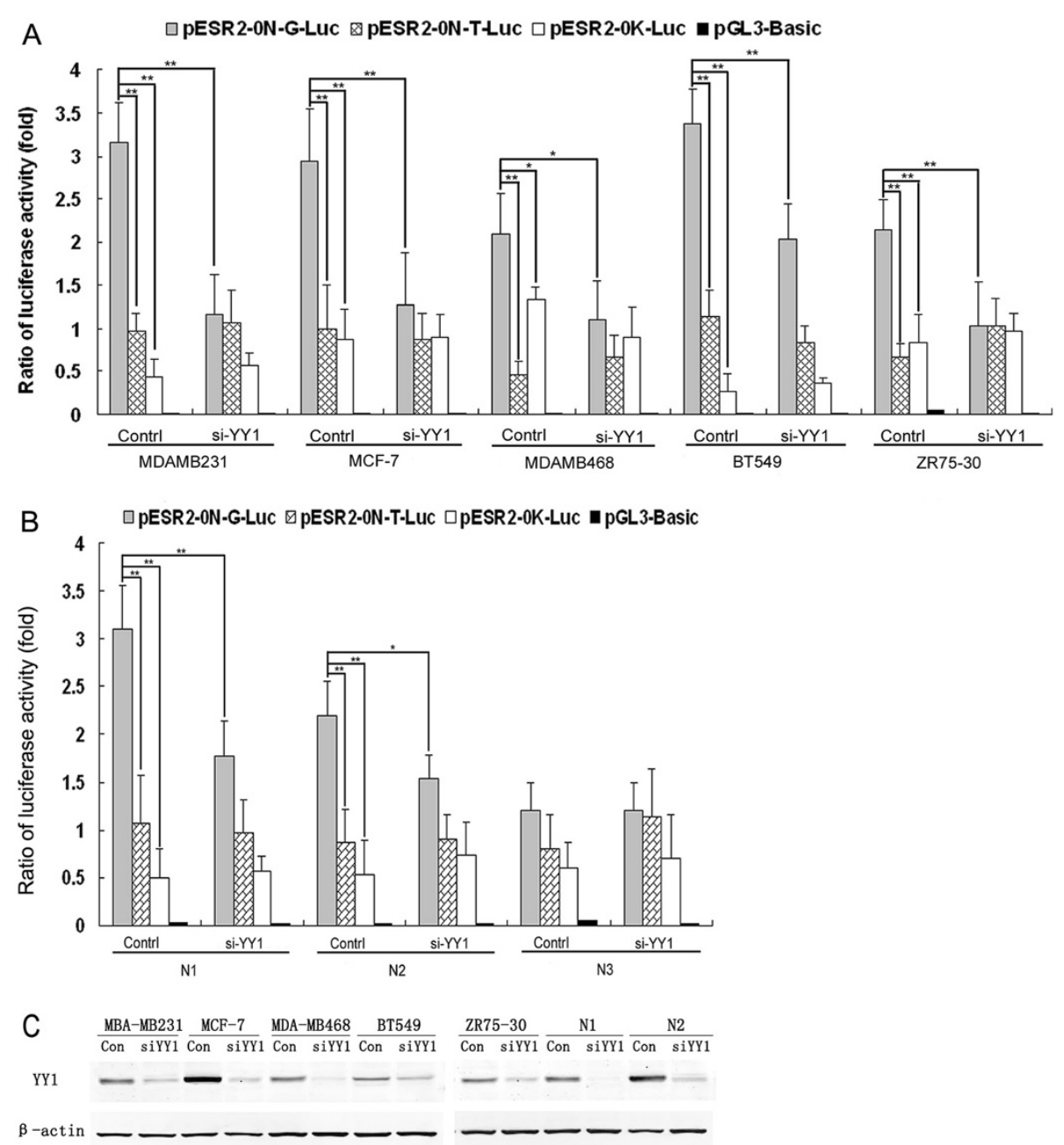

Figure 6 The T allele of rs 1271572 down-regulated the activity of the ER $\beta$ promoter 0 N.A). The human breast cancer cells (MDA-MB-231, MCF-7, MDA-MB-468, BT-549 and ZR75-30) were transfected with the normalization control vector pRL and each of the pESR2-0 N-G-Luc, pESR2-0 N-T-Luc, pESR2-0 K-Luc (promoter $0 \mathrm{~K}$ ) alone, or together with the YY1-specific siRNA oligos. Lucifease activities of these reporters were determined using the dual luciferase assay kit. B). Primary breast cancer cells (N1, N2 and N3) were transfected with the vectors as in $\mathbf{A}$ ) and luciferase activity was determined. The figure represents the results of three independent experiments. ${ }^{*} p<0.05 ;{ }^{* *} p<0.01$. Graphs show means +- S.E.M. $(\mathrm{n}=8)$. C). The human breast cancer cell lines (MDA-MB-231, MCF-7, MDAMB468, BT549 and ZR75-30) and the primary breast cancer cells (N1 and N2) were transfected with YY1-specific siRNA oligos and YY1 expression was examined by western blot. $\beta$-actin was used to confirm equal protein loading. Each lane was loaded with up to $30 \mu \mathrm{g}$ of protein.

Compared with GT and GG genotypes, the TT genotype of rs1271572 was associated with low ER $\beta$ expression (Figure 1). The in vitro luciferase assays showed that the rs1271572 $\mathrm{G} \rightarrow \mathrm{T}$ allele could reduce the transcription activity of promoter $0 \mathrm{~N}$ in ER $\beta$ gene expression (Figure 6A and $6 \mathrm{~B}$ ). These results suggest that the $\operatorname{rs} 1271572 \mathrm{G} \rightarrow \mathrm{T}$ allele is associated with the inhibition of expression of the ER $\beta$ gene in patients with breast cancer. Bioinformatics tools predicted that the $\mathrm{rs} 1271572 \mathrm{G} \rightarrow \mathrm{T}$ allele led to the loss of binding of the YY1 transcription factor (Figure 4).

Yin Yang 1 (YY1) transcription factor is highly expressed in various types of cancers and regulates tumorigenesis through multiple pathways. YY1 is generally overexpressed in breast cancer cells and tissues, and YY1 is an oncogene which negatively regulates p27. [31]. YY1 is a multifunctional protein that plays a fundamental role in normal biological processes such as embryogenesis, differentiation, replication, and cellular proliferation in vertebrates $[32,33]$. The reduction of inhibition of YY1 expression promoted cell migration and resulted in an invasive phenotype in breast cancer cells [34]. Pathway meta-analyses identified a number of important factors, including the YY1 transcription factor that were implicated in the metastasis of breast cancer [35]. We thus hypothesized that the TT genotype of rs1271572 suppressed ER $\beta$ expression by inhibiting YY1 binding. In support of this hypothesis, no DNA-protein 
complex was formed with synthetic probes that contain sequence from rs1271572T region (Figure 5). Moreover, knockdown of YY1 in breast cancer cells lines and primary breast cancer cultures also decreased the transcriptional activity of the promoter $0 \mathrm{~N}$ (Figure 6). Further mechanistic studies will be needed to identify additional key factors through which rs1271572 TT regulate the expression of ER $\beta$ expression in breast cancer.

\section{Conclusion}

In this study we report that Chinese women with the TT genotype of rs1271572 had a significantly higher risk of breast cancer and have a poor prognosis and were more likely to suffer brain metastasis. The homozygous TT genotype of rs1271572 was associated with low ER $\beta$ expression in breast cancer patients. Further mechanistic studies revealed that TT genotype of rs1271572 resulted in loss of the YY1 binding site and reduced the transcription activity of the promoter $0 \mathrm{~N}$ in the ER $\beta$ gene.

\section{Additional files}

Additional file 1: Figure S1. Structure of the human ERß gene. Exons are represented by boxes and introns by lines. The number below each box indicates the size of the exon (bp); the number above each line indicates the size of the intron (bp).

Additional file 2: Table S1. PCR primers used for the ER $\beta$ gene SNP analyses.

Additional file 3: Figure S2. Schematic representation of the $5^{\prime}$ untranslated region of human ERß. The translation start site is indicated by ATG. A of the first codon ATG is assigned nucleotide number +1 . Exons are represented by gray boxes and introns by lines. The dotted lines between the gene promoter and the DNA fragment indicate how the fragments were constructed. ESR2-0 N-indicates the DNA sequence of the ER $\beta$ promoter $0 \mathrm{~N}$ and the inserted partial upstream sequence of the intron to ATG of exon 1. ESR2-0 K+indicates the DNA sequence of the ERß promoter $0 \mathrm{~K}$ and the inserted partial upstream sequence of intron to ATG of exon 1.

Additional file 4: Table S2. Genotype frequencies for SNPS in the ERR gene promoter in Chinese breast cancer patients, fibroadenoma patients and blood donors.

Additional file 5: Table S3. Relationship between the genotypes of rs1271572 and clinicopathological factors in patients with breast cancer.

\section{Abbreviations}

YY1: Yin Yang 1 transcription factor; ERa: estrogen receptor alpha; ERB: estrogen receptor beta; SNP: Single nucleotide polymorphisms; PCR: Polymerase chain reaction; EMSA: Electrophoretic mobility-shift assay; HER2: Human epidermal growth factor receptor 2; PgR: Progesterone receptor.

\section{Competing interests}

The authors declare that there are no conflicts of interests.

\section{Authors' contributions}

LC designed and performed research experiments, analyzed data, and wrote the manuscript, YL collected patients data and samples, performed experiments, JQ, LZ and XC performed some experiments, analyzed the data, provided cells and reagents, $\mathrm{XL}$ and JJ reviewed and edited the manuscript, provided suggestions to the research. All authors read and approved the final manuscript.

\section{Acknowledgments}

This work was supported by grants from the National Natural Science Foundation of China (No.81072157) and the Clinical Research Foundation of the Third Military Medical University (No 2010XLC12). The authors would like to thank the people who participated in this study.

Received: 9 February 2013 Accepted: 21 May 2013

Published: 28 May 2013

\section{References}

1. Ferlay J, Shin HR, Bray F, Forman D, Mathers C, Parkin DM: Estimates of worldwide burden of cancer in 2008: GLOBOCAN 2008. Int J Cancer 2010, 127:2893-2917.

2. Chen XY, Kong ZL: Chinese Cancer Registry Annual Report 2009. In Book [Chinese Cancer Registry Annual Report 2009]. Edited by Press Military Medical Science; 2010:26-28.

3. $\mathrm{Li} \mathrm{GL}$, Chen WQ: Representativeness of population-based cancer registration in China-comparison of urban and rural areas. Asian Pac $J$ Cancer Prev 2009, 10:559-564.

4. Yu KD, Rao NY, Chen AX, et al: A systematic review of the relationship between polymorphic sites in the estrogen receptor-beta (ESR2) gene and breast cancer risk. Breast Cancer Res Treat 2011, 126:37-45.

5. Chen L, Qiu J, Yang C, et al: Identification of a novel estrogen receptor beta1 binding partner, inhibitor of differentiation-1, and role of ERbeta in human breast cancer cells. Cancer Lett 2009, 278:210-219.

6. Fox EM, Davis RJ, Shupnik MA: ERbeta in breast cancer-onlooker, passive player, or active protector? Steroids 2008, 73:1039-1051.

7. Roger $P$, Sahla ME, Mäkalä S, et al: Decreased expression of estrogen receptor beta protein in proliferative preinvasive mammary tumors Cancer Res 2001, 61:2537-2541.

8. Treeck $\mathrm{O}$, Elemenler E, Kriener C, et al: Polymorphisms in the promoter region of ESR2 gene and breast cancer susceptibility. J Steroid Biochem Mol Biol 2009, 114:207-211.

9. Maguire P, Margolin S, Skoglund J, et al: Estrogen receptor beta (ESR2) polymorphisms in familial and sporadic breast cancer. Breast Cancer Res Treat 2005, 94:145-152.

10. Gold B, Kalush F, Bergeron J, et al: Estrogen receptor genotypes and haplotypes associated with breast cancer risk. Cancer Res 2004, 64:8891-8900.

11. Ichikawa S, Koller DL, Peacock M, et al: Polymorphisms in the estrogen receptor beta (ESR2) gene are associated with bone mineral density in Caucasian men and women. J Clin Endocrinol Metab 2005, 90:5921-5927.

12. Nilsson M, Dahlman I, Jiao H, et al: Impact of estrogen receptor gene polymorphisms and mRNA levels on obesity and lipolysis - a cohort study. BMC Med Genet 2007, 8:73.

13. Harendza S, Lovett DH, Panzer U, et al: Linked common polymorphisms in the gelatinase a promoter are associated with diminished transcriptional response to estrogen and genetic fitness. J Biol Chem 2003, 278:20490-20499.

14. Stevens A, Soden J, Brenchley PE, et al: Haplotype analysis of the polymorphic human vascular endothelial growth factor gene promoter. Cancer Res 2003, 63:812-816.

15. Hirata $S$, Shoda T, Kato J, et al: The multiple untranslated first exons system of the human estrogen receptor $\beta$ (ER $\beta$ ) gene. J Steroid Biochem Mol Biol 2001, 78:33-40.

16. Zhao C, Lam EW, Sunters A, et al: Expression of estrogen receptor $\beta$ isoforms in normal breast epithelial cells and breast cancer: regulation by methylation. Oncogene 2003, 22:7600-7606.

17. Kim BC, Kim WY, Park D, et al: SNP@Promoter: a database of human SNPs (single nucleotide polymorphisms) within the putative promoter regions. BMC Bioinforma 2008, 1:S2. 9 Suppl.

18. MARIE-GENICA consortium on genetic susceptibility for menopausal hormone therapy related breast cancer risk, Abbas S, Beckmann L, et al: Polymorphisms in genes of the steroid receptor superfamily modify postmenopausal breast cancer risk associated with menopausal hormone therapy. Int J Cancer 2010, 126:2935-2946.

19. Breast and Prostate Cancer Cohort Consortium, Cox DG, Bretsky P, et al: Haplotypes of the estrogen receptor beta gene and breast cancer risk. Int J Cancer 2008, 122:387-392.

20. Sun $Y H$, Yang $B$, Wang $X H$, et al: Association between single-nucleotide polymorphisms in estrogen receptor beta gene and risk of prostate cancer. Zhonghua Wai Ke Za Zhi 2005, 43:948-951. 
21. Qi J, Zhang J, Feng W, et al: Promoting effect of IFN-gamma on the expression of LPS-induced IL-12 p40 and p35 mRNA in murine suppressor macrophages. Sci China C Life Sci 2000, 43:578-588.

22. Figtree GA, Noonan JE, Bhindi R, Collins P: Estrogen receptor polymorphisms: significance to human physiology, disease and therapy. Recent Pat DNA Gene Sea 2009, 3:164-171.

23. Herynk MH, Fuqua SA: Estrogen receptor mutations in human disease. Endocr Rev 2004, 25:869-898.

24. Fischer C, Juhasz-Boess I, Lattrich C, et al: Estrogen receptor beta gene polymorphisms and susceptibility to uterine fibroids. Gynecol Endocrinol 2010, 26:4-9.

25. Rexrode KM, Ridker PM, Hegener HH, et al: Polymorphisms and haplotypes of the estrogen receptor-beta gene (ESR2) and cardiovascular disease in men and women. Clin Chem 2007, 53:1749-1756.

26. Ye S, Dhillon S, Xiayi K, Collins AR, Day IN: An efficient procedure for genotyping single nucleotide polymorphisms. Nucleic Acids Res 2001, 29:88-98.

27. Vinayagam R, Sibson DR, Holcombe C, et al: Association of oestrogen receptor beta 2 (ER beta 2/ER beta CX) with outcome of adjuvant endocrine treatment for primary breast cancer-a retrospective study. BMC Cancer 2007, 7:131.

28. Lindberg K, Ström A, Lock JG, et al: Expression of estrogen receptor beta increases integrin alpha1 and integrin beta1 levels and enhances adhesion of breast cancer cells. J Cell Physiol 2010, 222:156-167.

29. Gruvberger-Saal SK, Bendahl PO, Saal LH, et al: Estrogen receptor beta expression is associated with tamoxifen response in ERalpha-negative breast carcinoma. Clin Cancer Res 2007, 13:1987-1994.

30. Rakha EA, Reis-Filho JS, Ellis IO: Combinatorial biomarker expression in breast cancer. Breast Cancer Res Treat 2010, 120:293-308.

31. Wan M, Huang W, Kute TE, Miller LD, Zhang Q, Hatcher H, Wang J, Stovall DB, Russell GB, Cao PD, Deng Z, Wang W, Zhang Q, Lei M, Torti SV, Akman SA, Su G: Yin Yang 1 plays an essential role in breast cancer and negatively regulates p27. Am J Pathol 2012, 180:2120-2133.

32. Gordon S, Akopyan G, Garban H, et al: Transcription factor YY1: structure, function, and therapeutic implications in cancer biology. Oncogene 2006 25:1125-1142.

33. Gordon $\mathrm{S}$, Akopyan $\mathrm{G}$, Garban $\mathrm{H}$ : $\mathrm{YY} 1$ is autoregulated through its own DNA-binding sites. BMC Mol Biol 2009, 10:85.

34. Lieberthal JG, Kaminsky M, Parkhurst CN, et al: The role of YY1 in reduced HP1alpha gene expression in invasive human breast cancer cells. Breast Cancer Res 2009, 11:R42.

35. Thomassen M, Tan Q, Kruse TA: Gene expression meta-analysis identifies metastatic pathways and transcription factors in breast cancer. BMC Cancer 2008, 8:394.

doi:10.1186/1423-0127-20-32

Cite this article as: Chen et al:: Significance of rs 1271572 in the estrogen receptor beta gene promoter and its correlation with breast cancer in a southwestern Chinese population. Journal of Biomedical Science 2013 20:32.

\section{Submit your next manuscript to BioMed Central and take full advantage of:}

- Convenient online submission

- Thorough peer review

- No space constraints or color figure charges

- Immediate publication on acceptance

- Inclusion in PubMed, CAS, Scopus and Google Scholar

- Research which is freely available for redistribution 